\title{
Tribute to Deshamanya Dr. S. Ramachandran
}

\author{
Journal of the Ceylon College of Physicians, 2010, 41,92-93
}

Suren to some of us and Rama to others was certainly one of the outstanding physicians of our time. Born to a well known Tamil hindu family, he had his early education at CMS Ladies College Colombo and then Royal College Colombo. He entered the Science Faculty of the University of Colombo in 1951 and the Faculty of Medicine in 1952. His undergraduate career was absolutely brilliant, obtaining first classes in the 2nd, 3rd and final MBBS examinations with distinctions in Physiology, Biochemistry, Pharmacology, Pathology, Bacteriology, Medicine, Surgery, Obstetrics and Gynaecology. In the process, he was awarded the Vaithilingam Gold medal in Physiology, Loos Gold medal in Pathology, Andrew Caldecott gold medal for the best performance in the final MBBS, Dadabhoy Gold medal for Medicine and the Perry exhibition for the best performance in the final MBBS.

He obtained the MD Ceylon in 1961 - the only successful candidate among 18 who sat for the exam. He was then awarded the British Council scholarship and trained in the University College Hospital, London. He obtained the membership of the Royal Colleges of Physicians London, Glasgow and Edinburgh in quick succession. On his return to Ceylon, he worked as a consultant physician to the Batticaloa, Negombo and Ragama General Hospitals and thereafter assumed duties as a Consultant Physician in 1977 at the then General Hospital, Colombo. Here he served for 17 years until his retirement from Government service in 1994. In between these appointments, he was awarded the Smith and Nephew Fellowship to the UK in 1969, where he trained in the renal unit at the Royal Free Hospital, London. On his return, he was appointed as the first Physician in charge of the dialysis unit, General Hospital, Colombo which was the first unit in the country with facilities for dialysis. He also served in the administrative committee of the medical intensive care unit at the hospital from its inception in 1982 until his retirement in 1994.

He published his research on various topics in general medicine. These included hepatic amoebiasis, leptospirosis, malaria, typhoid, diabetes, alcoholism and disorders of the elderly. His papers were widely quoted in local and foreign indexed medical journals. His contribution on various aspects of nephrology has indeed been vast. He also contributed to many studies on snake bite. He presented his research findings both locally and internationally in India, Pakistan, Indonesia, China, Australia, New Zealand, Malaysia, Singapore, Taiwan and Bangladesh. He was an invited speaker at the World Congress of Nephrology in Sydney in 1997. He taught and trained many batches of doctors on various aspects of haemodialysis and four of them are presently qualified Nephrologists. He can truly be called the "Father of Nephrology" in Sri Lanka.

He was honoured by being invited to deliver the Marcus Fernando Oration on three occasions, on "Renal Complications of Diabetes", "Hepatic Amoebiasis" and "Problems in Renal Failure". He also delivered the S.C.Paul Oration twice, on the "Young Diabetic", and "Alcoholism and Drug Addiction", the P.B.Fernando Oration on "Medical Problems of the Elderly", the Kandy Society of Medicine Oration on "Renal Failure" and the Pasupathi Memorial Oration on "Aalcoholic Liver Disease". He was awarded the fellowships of the Royal Colleges of London, Edinburgh and Glasgow, the Ceylon College of Physicians, the American College of Physicians and the College of General Practitioners of Sri Lanka.

He held responsible positions in academic bodies such as the Sri Lanka Medical Association as council member, treasurer and later as its President in 1997 98 and as a member of its expert committees on snake bite and rabies. He was a member of the Asian Pacific Society of Nephrology, Asian Pacific Colloquium in Nephrology, the New Zealand and Australian Societies of Nephrology and the International Society of Nephrology.

His services to the Ceylon College of Physicians were enormous. He served on its council for many years, Vice President in 1988-89, and President in 1990-91. During his Presidency he initiated a new series of lectures called the "College Lectures" and the "Young Physician's Forum" where 20 young Physicians addressed the College on various topics of current interest during the year. These lectures have been continued to date. He also initiated the "Wijerama Endowment Aaward" to honour the College's first President. The "Medicine Update" a summary of important articles from current medical literature was also his brain child and this too has continued to date. 
Joint meetings with other Colleges such as that of Surgery, Obstetrics and Gynaecology, General Practitioners and the Paediatric Association was another of his innovations.

He was a good teacher and was always ever ready to share his expertise with others. He strived for excellence in all his activities, none more so than in his chosen speciality of General Medicine and Nephrology. He inculcated the "cover to cover" approach of study of the various medical text books of his time to his protégés. He was a very cordial person with a warm welcoming smile; his hearty "back slap" or "hand tap" were his characteristic hall marks.

For his services to the Country he was awarded the title of Deshabandu in 1990 and crowned it with the title of Deshamanya in 1994. His interests were not confined to Medicine alone. He was a fine artist and portrait painter and some of his handiwork could be seen in his home at Ward Place. He was also a lover of carnatic music and used to travel to Jaffna and South India regularly to listen to great artists play their music at the grand Hindu Festivals. He was also a great traveler visiting many countries to see and appreciate their different cultures and was a specialist in famous buildings of different religious backgrounds. He was a devout Hindu and practiced his beliefs in a quiet and unostentatious way. To me personally he was a great mentor, advisor, colleague, friend and inspiration. I consider myself privileged to have known and moved closely with this great Physician of my time.

To his wife Nirmala, his companion and partner for 49 years and their son Sudharshan and family I extend my condolences in their great loss. The Ceylon College of Physicians will also miss his presence at their various ceremonial occasions and his advice. He was indeed a great son of Sri Lanka.

\section{H N Rajaratnam}

